\title{
Using Android Media for Chemistry Learning Construction of Motivation and Metacognition Ability
}

\author{
Anggun Dwi Astiningsih \\ Graduate Student of Chemistry Education, Graduate School, Universitas Negeri \\ Yogyakarta, Indonesia, anggunda15.2017@student.uny.ac.id
}

Crys Fajar Partana

Dr, Department of Chemistry Education, Graduate School, Universitas Negeri Yogyakarta, Indonesia, crsfajar@gmail.com

The 21 st century and industry revolution 4.0 has been technology used part of life. This research intended to understand the effect of android application for chemistry learning (reaction rate material) to construction of motivation and metacognition of high school students. Research aimed to determine the worthiness and effectiveness of chemistry learning using android with Research and Development $(R \& D)$ method of $4 \mathrm{D}$ by Thiagarajan and experiment method. The instruments used in this research consist of experts' validation sheets, chemistry teachers sheets, peer reviewer sheets and students response sheets, and also test with metacognition indicators. The data were analyzed by using descriptive quantitative method with empirical analysis and MANOVA, involving two experts on topic material and media aspects, chemistry teachers and peer reviewer: the results show that on worthy grade. The result on the questions test metacognition ability and motivation sheets of trial analysis test was fit and valid questions. Therefore, the response sheets the students using android media for chemistry learning had a great influence on transfer chemistry material content of high school students. The application android was significantly effective for students metacognition ability on effect-size interpreted as large effect, but in students study motivation was not significantly effective on effect size as small effect.

Keywords: android application media, chemistry learning, reaction rate material content, metacognition ability, motivation

\section{INTRODUCTION}

The millennial transformation era on education of the 21 st century, science education and technology is growing very rapidly in Indonesia was no exception. The current changes occurring in the learning activities that involve educators and learners. 
Educators are expected in the professional development of educators not only with learning learners, but also for managing information to facilitate learning activities by adding sources and appropriate learning media with the Government Regulation number 19-year 2017 stating that educators have the competence to use information and communication technology functionally corresponding to 2013 curriculum for more innovative. The times of the current science and technology rapidly but underutilized by most educators in learning, because it is tied to a very solid time teaching and constraints in the mastery of technology (Liliarti \& Kuswanto, 2018). Nowadays the majority of learners can be said to be a gadget addict (mobile/smartphone addicted to playing games). Therefore, in support of 4.0 industry revolution and 21 st century educator must be prepared to face the challenges in learning due to the revolution of science and technology (Higgins, Xiao, \& Katsipataki, 2012).

The use of technology can also be used in learning to be more interactive and engaging students in learning. Such as android or smartphone technology that is used as a medium of learning can provide a learning material application has efficient and effective impacts that can be downloaded by learners in accordance with the material required, so it can be repeated anytime studied alone (Jengathe, Dinesh, \& Rojatkar, 2015). The Government was already doing a wide range of facilities such as the existence of technological training by educator and internet connections in schools, but it is still not yet underutilized for some educators who have not interested with technology (Arista was \& Kuswanto, 2018). So, need for more guidance on learning media and follow-up for an internet connection immediately technology in various areas for the use of the media learning android a more communicative (Hanafi \& Samsudin, 2012).

One of the learning of science namely chemical learning, learners most difficult experienced in understanding the concept of chemistry. It is now evident that many learners after learning at the school follow the extra tutoring in the learning or more. Chemical material which make disposed difficult by learners in learning that is one material reaction rate. Material chemical rate proved elusive by the learners about the collision, order of reaction or equation calculations reaction associated with the factors of reaction rate (Sumargo \& Yuanita, 2014). The national examination (UN) chemistry, material reaction rate is one of the obligatory materials in question is usually 2 to 3 reserved. As in the news from (Kemendikbud, national examination of Senior High School in Indonesia 2018: the average value of math, physics and chemistry down, 2018) for high school grade or equivalent academic year 2017/2018, the decline took place based on the analysis of the existence of indication that because High Order Thingking Skills (HOTS) and national examination model changes from paper-based to computer-based. As well as the large number of chemical materials that must be understood and mastered making the learners quickly get bored and less interested in following chemical learning well, so it is important for educators looking for an effective way so that learners are motivated against the lessons of chemistry. One way is by designing instructional media for the chemical so that learning the concepts of chemistry can be used for the future and learners more motivated with the help of media technology-based or android to content material so that students are accustomed to working on the problems with media technology (Yektyastuti \& Ikhsan, 2016). 
Learning media needs are also related to the need for teaching such as media supplement technology one of the supporting reference to facilitate students to learn metacognition which is one of the primary implications of research on science teaching and learning activities that have emerged over the last 3 decades and on learning in science education. Metacognition appears already the last 5 years was no exception in Chemistry learning (Mathabathe \& Potgieter, 2014). In fact, in the education of the majority of the students from different backgrounds (derived from a heterogeneous environment) in the form of involvement of the thinking process. Study of chemistry at school and in the University in terms of knowledge must have a factual knowledge, conceptual, procedural and metacognition in science (Mathbathe \& Potgieter, 2017). Development of competencies of metacognition is a desired outcome in science education since making learning meaningful and important in the future. Metacognition in which a person can control his mind by designing, monitoring and evaluating the judge (expert) because of the expertise to know the ability of each learner what he had learned. So, hopefully the use of media technology in the learning process is one effort to learning related to content material more meaningful, in this case for chemical material more specifically. As in reference other research shows that by learning to use media or digital technology more meaningful in terms of metacognition learners than non-digital (Norman \& Fornes, 2016).

Learners have trouble understanding the chemical material and feel bored in learning chemistry, one of the factors which affected it i.e. participants less motivated students to learn the material Chemistry (Austin, Hammond, Barrows, Gould, Gould, \& 2018). Based on interviews of several chemical teacher in Banyumas region not yet using android-based learning media for curriculum 2013 learning due to constraints regarding time and need a solid teaching technology skill well just so accustomed to make the media. The reference used is still like a reference book (spreadsheet learners) circulating in the bookstore, learning media occasionally using power point and learning materials. As in the implementation of a national computer-based exam year 2018, for chemical subjects rarely chosen by learners for IPA (natural sciences concentration in senior high school in Indonesia). This means less motivated learners in learning the material. So expect to android-based media is one of learning application on smartphones containing chemical reaction rate material one of the learning support media supplements that are useful for learning students who can be used anywhere and anytime without the lesson time bound in School can support the technology media and also motivation of learners in learning Chemistry (Liu, Raker, \& Lewis, 2017).

Study the present and the future will be heavily influenced by the progress of science and technology (Sumadi, 2015). So, in 2013 as the standard curriculum implementation organization of education is a step to improve the quality of education and development of science and technology in the 21 st century today. Therefore, this research deals with media reaction rate after supporters who need an understanding of the concept and calculation of chemical that is considered difficult. So, the media application designed android on learning reaction rate based on 2013 curriculum to know the ability of Metacognition and learning motivation of learners. 


\begin{abstract}
METHOD
The method of this research is the use of quantitative methods of research and development (R\&D). This study followed by 4 steps (4D) from (Thiagarajan at al., 1974): Define, Design, Develop and Disseminate. Define: the definition of preliminary analysis includes: analysis of problems, learners, assignments, concepts and objectives of learning through library studies and field. Design: planning stage of media selection, format of formulation of reaction rate (material, reference, story board creation) and initial design of developed media product (Android based media). Develop: product development stages through expert validation (media expert, material expert, chemical teachers, peer reviewers, small-scale trials to learners) and product revision development test analysis, as well as test field learning of chemical reaction rates to the students and revise the product again. Disseminate: the stage of spreading the use of products to other schools and disseminated for example at International Seminar or submit to international journal about Android-based media development of chemical reaction rate material; In this study in the phase of disseminate of media is given to several schools and chemical teachers in the Banyumas region of Purwokerto and Purbalingga, Central Java, Indonesia.
\end{abstract}

\title{
Procedure and Participants
}

The research development was using 4D by Thiagarajan procedure that has been modified with stages: data collection (Define), planning (Design), the development of an initial draft, initial field tests that include small-scale trial and large-scale trial (Development) and revision of the test results and then Disseminate. After the initial draft is validated then conducted a small-scale trial, empirical test of metacognition test with sample 163 students and empirical test of motivation response sheets with 202 students trial held at Senior High School N 3 Purwokerto (Senior High School in Purwokerto, Central Java Region, Indonesia) and 8 chemistry teachers at several schools in the District of Banyumas (Purwokerto) and Purbalingga (Central Java, Indonesia). And also, with several peer reviewers for validation-media learning (application for android). The research subjects were Senior High School students: by means of probability sampling, 64 students at the Senior High School N 1 Sokaraja (Senior High School at Sokaraja Banyumas, Indonesia) were selected and divided into two groups; first half as an experiment class and the second half as a control class. The media business feasibility testing involved 32 students of Grade XI (the second grade of Senior High School), whom were yet to be given any lesson about reaction rate material content. The research was conduct at Senior High School N 1 Sokaraja (Senior High School at Sokaraja Banyumas Region, Central Java, Indonesia) from November to December 2018.

\section{Data Conducted and Analysis Techniques}

Data conducted techniques method using observations, methods of test and now with independent variable, namely media developed in the form of chemical learning on android applications, the dependent variable to know the ability of metacognition (test results evaluation test be reserved 7 description essay of the indicator with metacognition) and non-test in the form of the learning motivation questionnaire the 
learners. Research data sources include: the application of learning media assessmentbased material chemical reaction rate with android-based by the Validator (expert content, media experts, the chemical educators, peer reviewers), readability of media applications android on a small-scale trial. Assessment of the feasibility of using an instrument of validation of the modified eligibility (Crozat, Hu, Trigano \&, 1999) by Evaluation of Multimedia and Pedagogical Interactive Software (EMPI) and Learning Objects Review Instrument (LORI) developed by (Nesbit interpreted evidence Belfer, \& Vargo, 2002). The data obtained were analyzed using the validator from the data analysis of Aiken's to find out the validity of the content of an item (Aiken, 1985) States the level of quality of the media learning that qualitatively changed by conversion and reliability guidelines validation of developed media analyzed with make a score assessment service from expert lecturers, educators and peer reviewers. The validation results for media android applications are said to be reliability if the reliability score equal to or greater than $75 \%(\geq)$ (Widoyoko, 2011). The criteria of the assessment service shown in Table 1 as follows.

Table 1

Categories of Media Quality

\begin{tabular}{ll}
\hline Quantitative Score Categories & Criteria \\
\hline $\bar{x}>\bar{x}_{\mathrm{i}}+1,8 \mathrm{SBi}$ & Veri worthy \\
$\overline{x_{\mathrm{i}}}+0,6 \mathrm{SBi}<\bar{x}<\overline{x_{\mathrm{ii}}}+1,8 \mathrm{SBi}$ & Worthy \\
$\overline{x_{\mathrm{i}}}-0,6 \mathrm{SBi}<\bar{x}<\overline{x_{\mathrm{i}}}+0,6 \mathrm{SBi}$ & Adequate worthy \\
$\overline{x_{\mathrm{i}}}-1,8 \mathrm{SBi}<\bar{x}<\overline{x_{\mathrm{i}}}-0,6 \mathrm{SBi}$ & Less worthy \\
$\bar{x}<\overline{x_{\mathrm{i}}}-1,8 \mathrm{SBi}$ & Very less worthy \\
\hline
\end{tabular}

Note: $\overline{\bar{X}}_{\mathrm{i}}=$ the average ideal; $\overline{\bar{X}}_{\mathrm{i}}=1 / 2$ (highest score ideal + lowest score ideal); $\mathrm{SB}_{\mathrm{i}}=$ Ideally Byway raw; $\mathrm{SB}_{\mathrm{i}}=(1 / 2)(1 / 2)$ (highest score ideal + lowest score ideal); Highest score ideal $=$ the number of grains of the criteria $\mathrm{x}$ highest score; Lowest score ideal = the number of grains of the criteria $x$ lowest score.

Testing process of empirical matter tests, empirical testing metacognition question form the learning motivation of the learners are analyzed using the QUEST programs to find out the number of problem and now the statement fit for use in large-scale trials. The QUEST program's and internal consistency of empirical test instrument shown score reliability and interpretation of the score reliability instrument (Shabrina \& Kuswanto, 2018) in Table 2.

Table 2

Interpretation of Reliability Scores

\begin{tabular}{cl}
\hline Reliability Score & Interpretation \\
\hline $0.00-0.20$ & Less Reliable \\
$>0.20-0.40$ & Approximately Reliable \\
$>0.40-0.60$ & Adequate Reliable \\
$>0.60-0.80$ & Reliable \\
$>0.80-1.00$ & Very Reliable \\
\hline
\end{tabular}


Large scale trials data i.e. test android-based learning media effectiveness of reserved post-test evaluation using indicators of Metacognition and learning motivation of students now use MANOVA, and learner response against the android-based learning media developed, because this research aims to know the metacognition ability and motivation learn learners through the use of media-based learning material reaction rate on android. This study has used artificial experimentation field test with post-test only design which shown in Table 3 with random sample in two classes that was experiment class and control class.

Table 3

Post-test Group Design

\begin{tabular}{llll}
\hline Class & Pre-test & Treatment & Post-test \\
\hline Experimental & - & $\mathrm{X}_{1}$ & $\mathrm{O}_{1} \mathrm{M}_{1}$ \\
Control & - & $\mathrm{X}_{2}$ & $\mathrm{O}_{1} \mathrm{M}_{1}$ \\
\hline
\end{tabular}

Note: $\mathrm{X}_{1}=$ using the Android application chemistry learning media of reaction rate material; $\mathrm{X}_{2}=$ not using Android application learning media; $\mathrm{O}_{1}=$ post-test metacognition; $\mathrm{M}_{1}=$ post-test motivation sheets questioner

Test the collected statistics to find out the effectiveness of media material reaction rate android application using MANOVA analysis with SPSS program's 24. MANOVA test data entered score post-test data of metacognition ability and learning motivation questionnaire sheet learners who previously converted to using the method successive interval data Method of Successive Intervals (MSI) in advance. MANOVA test done if the prerequisites are met, namely for normality and homogeneity tests are met and shown from the test data Gaussian normality when Pearson correlation obtained high between -1 to +1 or sig. the mean level $0.05<$ of $\alpha=0.05$ (Pituch \& Stevens, 2016).

\section{FINDINGS}

The research development of android-based media in learning the material chemical reaction rate include: the description of the media that was developed, the results of the assessment of the feasibility of media android applications, small-scale test regarding validated and assessment for application android media (from a material and media expert, 8 chemistry teachers, peer reviewers), empirical tests of problem descriptions and empirical testing metacognition question form learning motivation, the results of the evaluation of post-test question of metacognition and learning motivation of learners now after learning process on large scale trials on experimental classes (using the android application) and control classes (not using an android application but use existing media in schools), as well as responses to learners on android applications on the classroom experiments. Based on the results of the research conducted is obtained the following data: in Table 2.

Android-based media development in the learning material chemical reaction rates compiled by the display of color and display animation and there is a chemical product, learning media accompanied by musical background sound form applications on android devices mobile in the Android format Package (apk) supporting application using i.e. Construct 2 for coding made learning media application and Photoshop to make design 
drawings. Media android application developed can be used as one of the innovations of the media learning material reaction rate for the students of Class XI (Second grade of Senior High School or equivalent curriculum 2013. Android applications in media learning developed contains information written in the Indonesian Language (information menu on the learning media and developer identity); the basic competencies and learning objectives; explanation of material reaction rate is divided into initial knowledge apperception, section later material in the form of understanding the reaction rate, the factors that affect the reaction rate associated with the theory of the collision, the order of the reaction, the reaction rate equation and ordinances; there are examples of reserved and exercises as well as discussion of the matter; and there is some level of problem gaming are made to train the learners thinking way in metacognition (from planning information, monitoring, and evaluation considering applying a way with different issue); there are animation related to chemistry in the media for learning developed to motivate learners in learning, examples of display media android applications this shown in Figure 1, Figure 2, Figure 3, and Figure 4. Android apps for learning media this chemical can be used without using the internet, so it can be used offline if the media was already installed on android phone. Initial display media learning android applications with the given colours and images that demonstrated the theme of material chemical reaction rates.

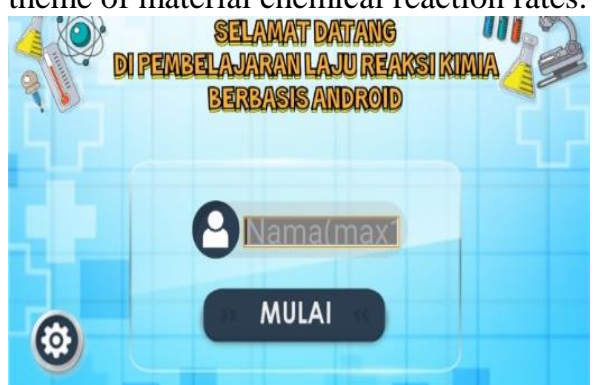

Figure 1

Initial Display Media Android Application Material Chemical Reaction Rates

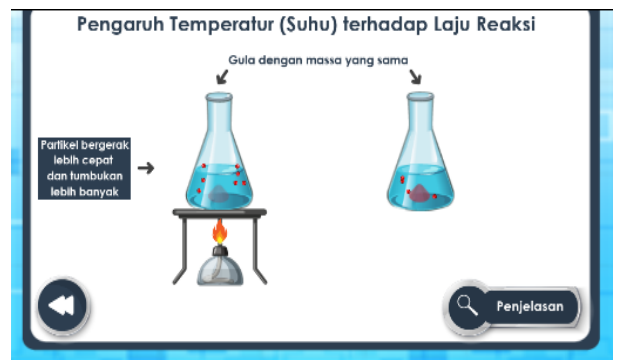

Figure 3

One example of the display of material factors that affect reaction rates

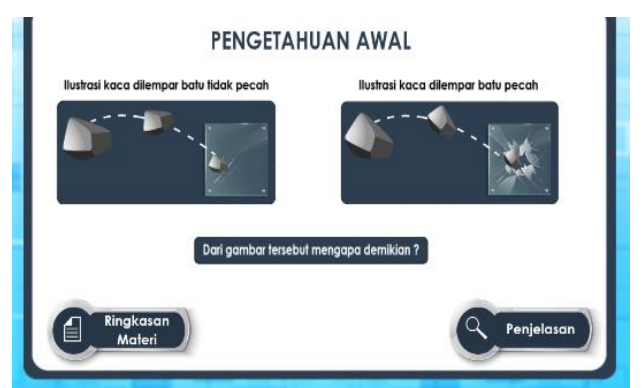

Figure 2

Display The Initial Reaction Rate Material

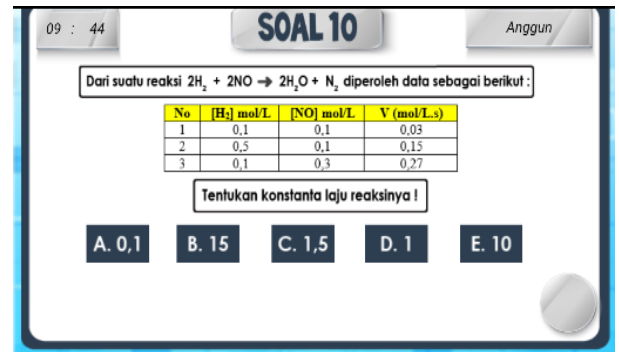

Figure 4

One example of the display of the game reserved reaction rates 
The results of the validation of the feasibility assessment media developed shown in Table 4.

Table 4

Media Validation Assessment Material Reaction Rate Android Application

\begin{tabular}{llllllll}
\hline Validator & \multicolumn{2}{c}{ Assessment Aspects } & & & Total \\
\cline { 2 - 6 } & Learning & $\begin{array}{l}\text { Material } \\
\text { Content }\end{array}$ & $\begin{array}{l}\text { Audio } \\
\text { Visual }\end{array}$ & Software & $\begin{array}{l}\text { Max } \\
\text { Score }\end{array}$ & Score & Criteria \\
\hline $\begin{array}{l}\text { Content } \\
\text { Expert }\end{array}$ & 15 & 22 & - & - & 37 & 50 & Worthy \\
\hline Media Expert & - & - & 16 & 25 & 41 & 50 & Worthy \\
\hline $\begin{array}{l}8 \text { Chemistry } \\
\text { Teachers }\end{array}$ & 17.6 & 26.5 & 18.1 & 25.6 & 88 & 100 & $\begin{array}{l}\text { Very } \\
\text { Worthy }\end{array}$ \\
\hline $\begin{array}{l}\text { 6 Peer } \\
\text { Reviewers }\end{array}$ & 18 & 28 & 18 & 27 & 91 & 100 & $\begin{array}{l}\text { Very } \\
\text { Worthy }\end{array}$ \\
\hline
\end{tabular}

The results of the responses to learners on a small-scale test shown in Figure 5.

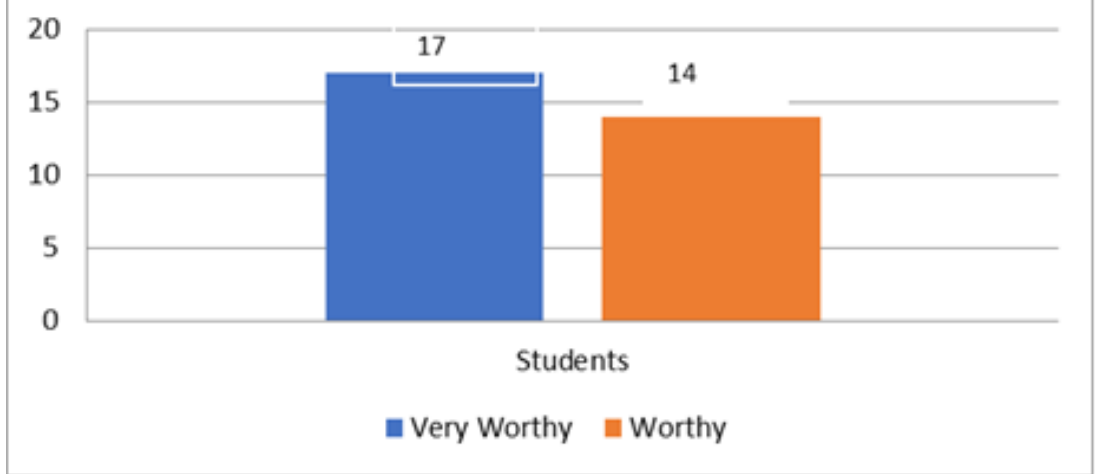

Figure 5

Assessment of Response Media Android applications on small scale Test

Once validated instruments on empirical test such as problem evaluation test instruments Metacognition and learning motivation questionnaire, next to know the reliability instrument using QUEST programs of empirical test data on learners as much as 163 to test and learner Metacognition as much as 202 for the questionnaire form of motivation to learn. Test instrument use indicators of Metacognition modified from Anderson \& Krathwohl there are 7 reserved essay tests and instruments now there are 20 learning motivation statements based on indicator motivation study of modified (Gonzalez \& Paoloni, 2015) (Scanlon, 2010) (Anderson \& Krathwohl, 2001) (Haryani, 2012) (Keller, John, \& Kopp, 2010). The results of the reliability test instrument Metacognition and learning motivation of learners now on empirical tests shown in Figure 6 and Figure 7. 
UJI COBA ANGGUN

Item Estimates (Thresholds)

oll on oll (N= $163 \mathrm{~L}=7$ Probability Level= .50)

Summory of item Estimates

Mean

SO (adjusted)

Reliability of estimate

Figure 6

The QUEST program and internal consistency of empirical test instrument shown score reliability and interpretation of the score reliability instrument in Table 2.

The result of the fit test question number metacognition and fit the now statements number of motivations questionnaire shown in Figure 8 and Figure 9.

UjI COBA ANGGUN

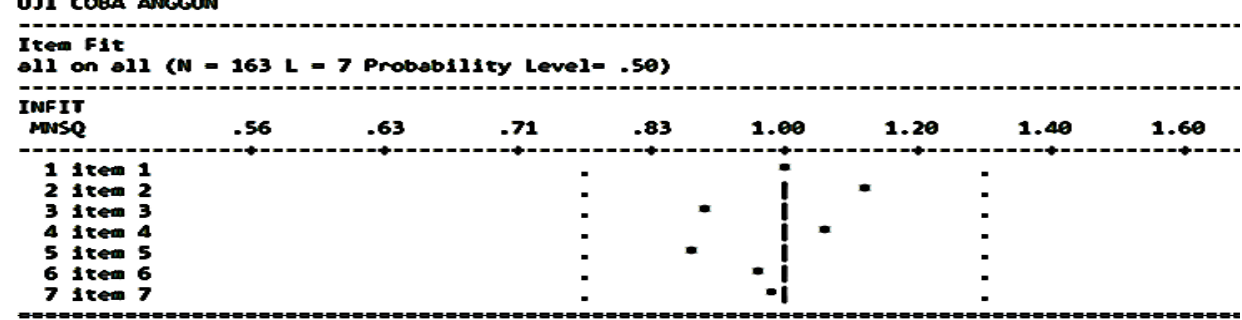

Figure 8

Analysis Fit of Metacognition Test

EmPIRIS MOTIVASI

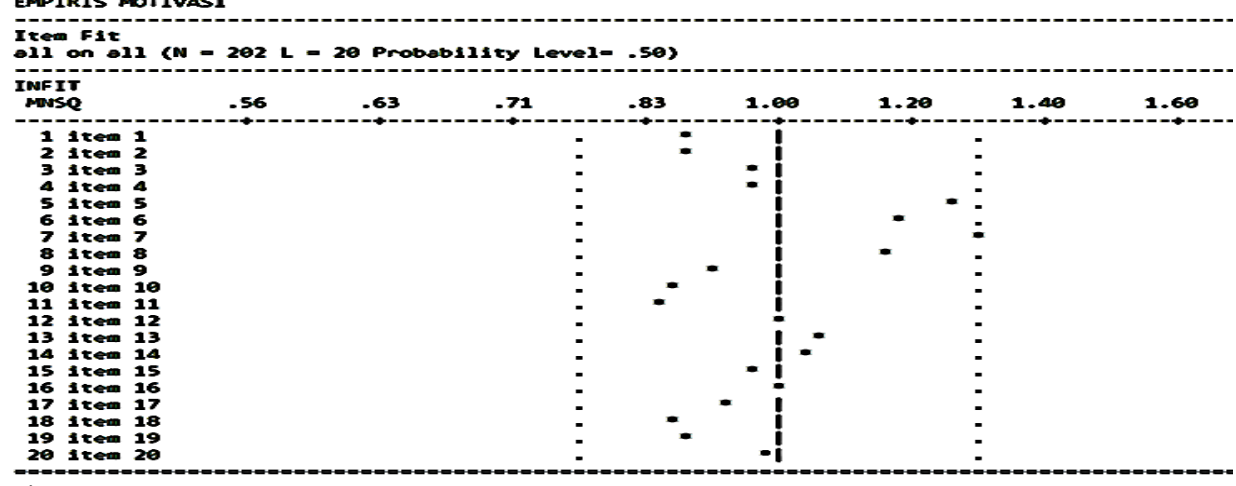

Figure 9

Analysis Fit of Motivation Questionnaires

Further research to find out the effectiveness of the using android media that is tested on a large scale in experiment class (using media applications android) and control class

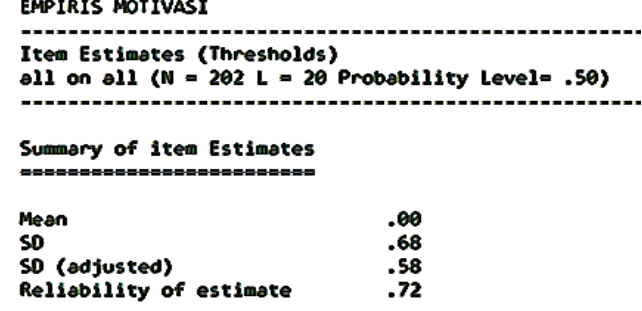

Figure 7 
(not using android application media but using references in daily used in schools) with MANOVA test using different responses between the 2 classes.

The learning process of learning material chemical reaction rates can be seen in Figure 10 and Figure 11, i.e., using media applications android on experiment class (Figure 10) and learning without using chemical media android on the control class (Figure 11). The results of the analysis of the average post-test the metacognition ability and learn motivation can be seen in the following Figure 12 .

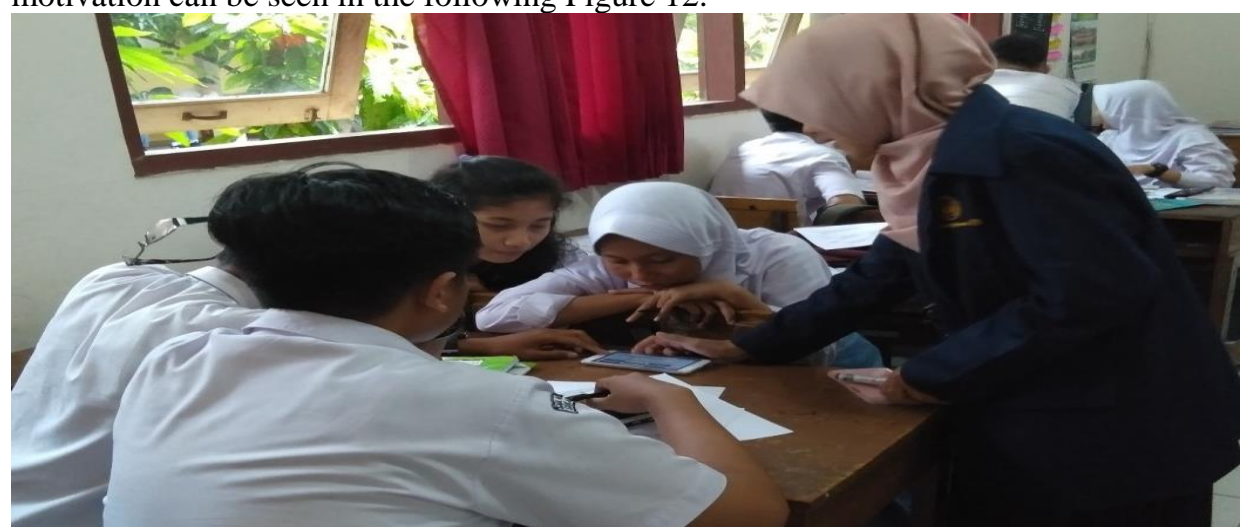

Figure 10

Learning Process on Experiment Class

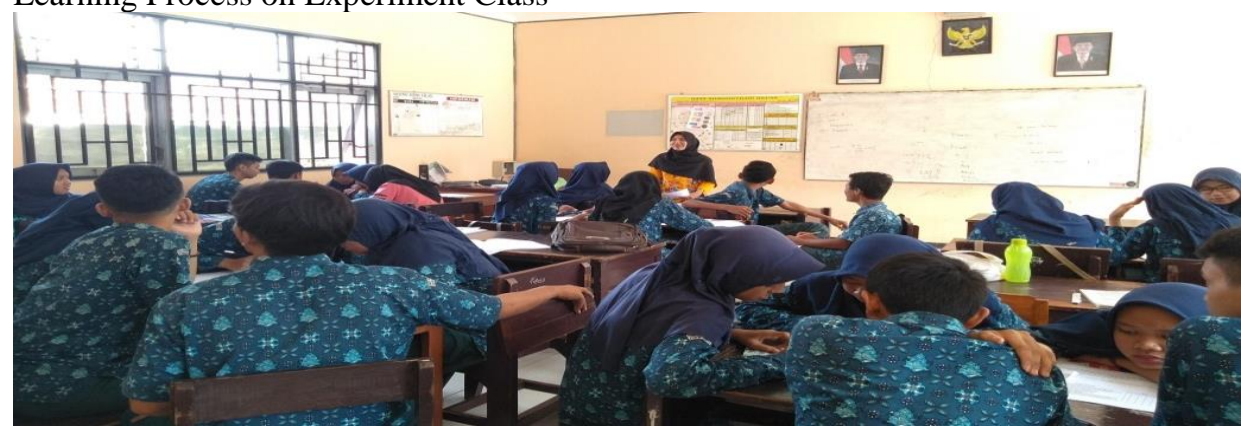

Figure 11

Learning Process on Control Class

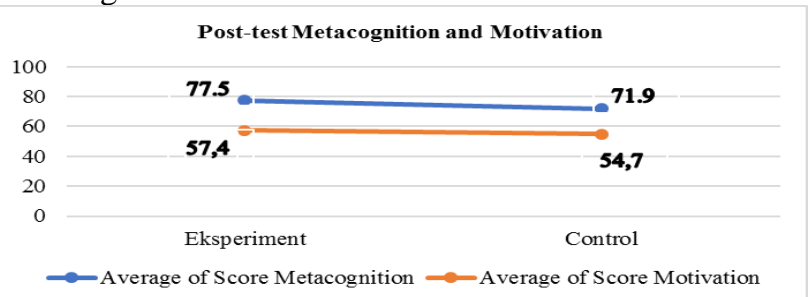

Figure 12

The Results of analysis Post-Test Metacognition and Motivation 
Multivariate normality test data shown on the graph of Mahanolobis multivariate (the lines on the Mahanolobis chart are approaching straight which means data is normal distribution) gaussian data in a scatter-plot tends to form a straight line (Figure 13) and shown from the test data Gaussian normality when Pearson correlation obtained high between -1 to +1 or sig. the mean level $0.05<$ of $\alpha=0.05$ that shown in Table 5 .

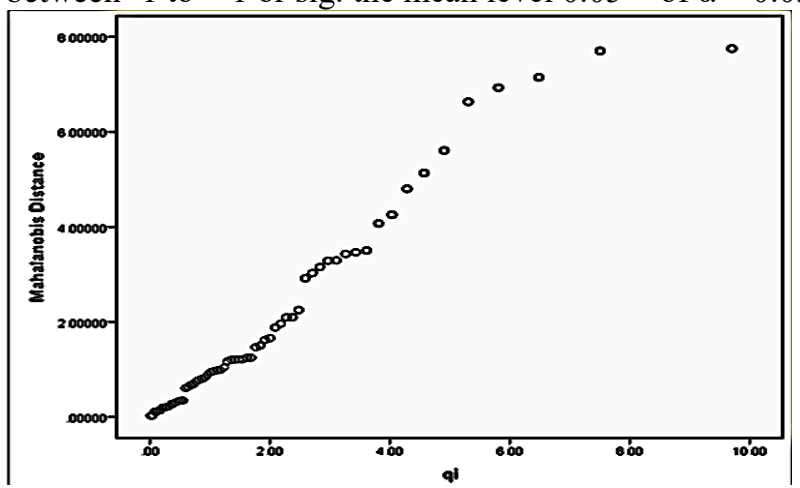

Figure 13

Multivariable Normality (Mahanolobis) Test Result

Table 5

Normality Test Result

\begin{tabular}{llll}
\hline Class & Pearson Correlation & Significance of Metacognition Ability & Significance of Motivation \\
\hline Experimental & 0.981 & 0.412 & 0.374 \\
Control & 0.981 & 0.075 & 0.702 \\
\hline
\end{tabular}

The homogeneity test determines the homogeneity of the dependent variable's variances matrix, analysis result of homogeneity test views on test Box's M on the Table 6.

Table 6

Homogeneity Test Result

\begin{tabular}{llllll}
\hline Variable & Box’s M & F & df1 & df2 & Sig. \\
\hline Metacognition and Motivation & 4.384 & 1.410 & 3 & 691920.0 & 0.238 \\
\hline
\end{tabular}

Based on Table 6 produced its homogeneity test Box'M analysis, score from sig. $0.238>$ $\alpha=0.05$ over; because of the agreement to the level of significance of $\alpha=0.05$, the dependent variable is a variant of a covariant data homogeneity.

The results of the analysis of Trace Hotteling's shown in Table 7.

Table 7

Results of Hotteling's Trace Multivariate Test

\begin{tabular}{lll}
\hline Effect Hotteling's Trace & Significance & Decision Criteria \\
\hline Intercept & 0.000 & sig. $<0.05$ \\
Media & 0.002 & sig. $<0.05$ \\
\hline
\end{tabular}

Based on Table 7 generated Hotteling's Trace score sig. 0.000 to intercept and sig. 0.002 to media which means the score sig. less than $\alpha=0.05$. This means for a level of significance of $\alpha=0.05$ less that the average of the two classes different significantly. 
Next calculate statistic test the size of the influence of effect android application media in the study of chemistry to know the metacognition ability and learning motivation of learners. The results of the analysis of the influence of media effects android applications shown in Table 8.

Table 8

Calculation Results of Effect Size on Metacognition Ability and Motivation

\begin{tabular}{lllll}
\hline Variable & Eta Squared & F & sig. & Interpretation \\
\hline Metacognition & 0.179 & 13.506 & 0.000 & Large Effect Size \\
Motivation & 0.038 & 2.430 & 0.124 & Small Effect Size \\
\hline
\end{tabular}

\section{DISCUSSION}

The results of the assessment feasibility of android apps developed media obtained from the assessment of this aspect of the presentation of the material and the media by experts' judgement from the Chemical Lecturer in Yogyakarta State University: media experts and material content expert. The feasibility of serving media android applications were also based on the assessment of the 8 Chemical Educators from several schools in the area of Banyumas and Purbalingga, Purwokerto in Central Java, Indonesia. As well as the assessment of some of the peer-reviewers (colleague) who researched the development of media. Based on Table 4 the results of the assessment indicate that the media android applications for learning material chemical reaction rates are included on the criterion of worthy and very worthy used in subsequent research used in small-scale trials and large-scale trials after validated by some experts. Although there are such media with revision exercises and writing problem clarified, after revision can be used for further research. Students response from small scale trial (31 students in class XII or 3rd grade at Senior High School who already get the material chemical reaction rate) was used to retrieve the data response learners against media android applications are developed.

Based on Figure 5. be aware that the media learning android application rate of a chemical reaction that has developed good use of readability and very good response by learners, is in line with research (Sari, Supahar, \& Ralmugiz, 2018) that the media Android provides a good effect on the influence of learning physics and science. The results of the assessment indicate that according to the learner's response against the media android application material reaction rate some learners voice reveals that background sound was replaced as it affects concentration, to exercise plus reserved and the discussion again. After a slight revision in the medium further developed android applications can be used on a large-scale trial to find out their effectiveness are tested on experimental class.

Based on Table 2 the results of the analysis of the empirical test QUEST program in Figure 6 and Figure 7 for reserved test score generated 0.73 Metacognition, it was meaning the category of "reliable" and the empirical analysis of the learning motivation of the now generated score 0.72 category "reliable". After the test known empirical question of Metacognition and learning motivation reliability question form, further results from QUEST program's views Infit MNSQ in between 0.77 to 1.33 means number reserved tests and statements of the now fit and can be used for further research. 
Based on Figure 8 all numbers reserved test Metacognition (7 items) are among a score of $0.77-1.33$, this means the fit question 7 there is no number questions banished (not deleted) and can be used for further research. So also in Figure 9 is invalidated analysis results i.e. 19 statement fit not disposed of and can be used for further research because between score $0.77-1.33$, while in a statement item number 7 is on the score limit of 1.33 which means items statement number 7 are discarded (deleted) due to approaching more than a score of 1.33 .

Based on the average score post-test metacognition in Figure 12 shown that the experiment class using media android apps (based on Figure 10) in a category higher than on an average value of control class refuses to use media android applications (based on Figure 11). These results are in line with research (Liliarti \& Kuswanto, 2018) that media use android applications can improve the competency think of representative on physics learning process. Research conducted by the (Sawuwu \& Pratama, 2018) stating that representations of chemical to stimulate reading metacognition in solving a test problem associated with indicators of metacognition. It is also in line with the research of (Liu, Raker, \& Lewis, 2017) that android-based media can support the motivation of learners in learning chemistry that is shown in Figure 10 on experimental class using media applications on average score from conversion of successive interval is higher than the class of control, although very few different but the media gave little effect on learning motivation of the learners.

The test results of multivariate normality in the experimental class and the control class each obtained the value of the normality of Shapiro-wilk greater than 0.05 so that it can be concluded that data derived from a population with a normal distribution of multivariate and based on the box's $M$ test shows that its significance value was greater than 0.05 namely 0.238 so that it can be concluded that the variant-covariance matrix of the homogeneous population. MANOVA test used statistics to make decisions from the hypothesis i.e. Hotteling's Trace because there are terms used only two groups of independent variables i.e. Metacognition and learning motivation (Khattree \& up, 2003). Based on Table 8. the resulting analysis score Cohen's variable $\mathrm{F}$ of metacognition of 13.506 meaning influential android application media of metacognition, this can also be seen from the score sig. 0.000 less than $\alpha=0.05$, namely Ha accepted which means the application android apps media effect on the ability of metacognition learners. This is in line with studies shows that by learning to use media or digital technology more meaningful in terms of metacognition learners than non-digital (Norman \& Fornes, 2016). As in research that chemical use learning strategies of metacognition gives a good influence on the science and quality of family learning learners and educators in the chemical thought with associated the concept of chemical materials (Parlan, Ibn, Rahayu, \& Suharti, 2018).

While the results of the analysis Table 8. score Cohen's f variable motivations of 0.038 which means the media give little effect against the motivation of learning, it can also be seen from the score sig. 0.124 meaning greater than $\alpha=0.05$, namely $\mathrm{H} 0$ are received the means the application of media android applications are not or less influence on the learning motivation of learners. These results give less influence on the learning motivation of students due to the level of motivation comes from family background 
differences the motivation, there are internal motivation (within oneself) and external motivation (environmental influences) as in research (Adegboyega, 2018). Learners came from different family backgrounds, age gender, so that can also affect their learning motivation, because motivation can also be influenced from the model of learning. In this study use of media less effect on motivation to learn and the learning experience of students in the school who have never used android apps media can also affect the motivation of learning educates participants (Hajhashemi, Caltabiano, Anderson, \& Tabibzadeh, 2017).

\section{CONCLUSION}

Based on the results of the development and research of Android-based media products is reviewed from the ability of students and motivation, can be concluded as follows: (1) media locally installed android application on Android and when installed, using application android media developed not requires an internet connection so that it can be used anytime and anywhere to learn the material reaction rate of chemical reaction; (2) an android application developed get good responses from some experts judgement (expert material and media expert), several chemical educators, several peer reviewers and some learners on a small scale trial of empirical test for all reserved Metacognition and motivation the result were simply reliability; (3) application android media developed provide considerable influence against the Metacognition ability of thinking, but just a tiny against the influential study learner motivation.

For future research: The Android application that has been developed can be researched its effectiveness through other types of research such as experimental research with different research subjects and using more classes. Media Android Application The rate of chemical reaction in this research can be developed again for the stages of presentation of material with different models or can also be expanded to another Android based chemical learning media for different material with more diverse types of games.

\section{REFERENCES}

Adegboyega, L. A. (2018). Influence of achievement motivation on nigerian undergraduates' attitude towards examination. International Journal of Instruction, 11(1), 77-88. https://doi.org/10.12973/iji.2018.1116a.

Aiken, L. (1985). Psichological testing and assesment. Boston: Allyn and Bacon.

Anderson, L., \& Krathwohl, D. (2001). A taxonomy for learning teaching and assesing: a revision of bloom's taxonomy of educational obsectives. New York: Addison Wesley Lonman.

Arista, S. F., \& Kuswanto, H. (2018). Virtual physics laboratory application based on the android smartphone to improve learning independence and conceptual understanding. International Journal of Instruction, 11(1), 1-16. https://doi.org/10.12973/iji.2018.1111a.

Austin, A., Hammond, N., Barrows, N., Gould, D., \& Gould, I. (2018). Relating motivation and student outcomes in general organic chemistry. Chemistry Education Research and Practice, 19, 331-341. https://doi.org/10.1039/c7rp00182g. 
Crozat, S., Hu, O., \& Trigano, P. (1999). A method for evaluating multimedia learning software. Florence: IEEE, 714-719. Retrieved from https://edutice.archivesouvertes.fr/edutice-00000399/document.

Gonzalez, A., \& Paoloni, P. V. (2015). Perceived autonomy-support, expectancy, value, metacognitive strategies and performance in chemistry: a structural equation model in undergraduates. Chemistry Educational Research and Practice, 16, 640-653. https://doi.org/10.1039/c5rp00058k.

Hajhashemi, K., Caltabiano, N., Anderson, N., \& Tabibzadeh, S. A. (2017). Multiple intelligences, motivations and learning experience regarding video-assisted subjects in a rural university. International Journal of Instruction, 11(1), 167-182. https://doi.org/10.12973/iji.2018.11112a.

Hanafi, H., \& Samsudin, K. (2012). Mobile learning environment system (MLES): the case of android-based learning application on undergraduates learning. International Journal of Advanced Computer Science and Application, 3(3), 63-66. https://doi.org/10.14569/IJACSA.2012.030311.

Haryani, S. (2012). Membangun Metacognition dan Karakter Calon Guru Melalui Pembelajaran Praktikum Kimia Analitik Berbasis Masalah. Semarang: UNNES.

Higgins, S., Xiao, Z., \& Katsipataki, M. (2012). The impact of digital technology on learning: a summary for the education edowment foundation. Durham: Durham University.

Jengathe, G., Dinesh, V., \& Rojatkar. (2015). Use of Android in the educational system. International Journal of Electrical and Electronics Research, 3(4), 133-137.

Khattree, R., \& Naik, D.N. (2003). Applied multivariate statistics with SAS software. New York: Wiley

Keller, J. M., \& Kopp, T. (2010). An application of the ARCS model of motivational design, dalam Charles M. Reigeluth (ed) instructional theories in action. Hillsdale, NJ: Lawrence Erlbaum Associates.

Liliarti, N., \& Kuswanto, H. (2018). Improving the competence of diagramatic and argumentative representation in physics through android-based learning application. International Journal of Instruction, 11(3), 106-122. https://doi.org/10.12973/iji.2018.1138a.

Liu, Y., Raker, J., \& Lewis, J. (2017). Evaluating student motivation in organic chemistry courses: Moving from a lecture-based to a flipped approach with peer-led team learning. Chemistry Education Research and Practice, 19(1), 251-264. https://doi.org/10.1039/c7rp00153c.

Mathabathe, K. C., \& Potgieter, M. (2014). Metacognitive monitoriung and learning gain in foundation chemistry. Chemistry Educational Research and Practice, 15, 94104. https://doi.org/10.1039/c3rp00119a.

Mathbathe, K. C., \& Potgieter, M. (2017). Manifestations of metacognitive activity during the collaborative planning of chemistry practical investigations. International Journal of Science Education, 39(11), 1-20. https://doi.org/10.1080/09500693.2017.1336808. 
Nesbit, J., Belfer, K., \& Vargo, J. (2002). A convergent participation model for evaluation of learning objects. Canadian Journal of Learning and Technology, 28(3), 105-120. http://dx.doi.org/10.21432/T25C8C.

Norman, E., \& Fornes, B. (2016). The relationship between metacognitive experiences and learning: is there difference between difital and non digital stufy media? Computers in Human Behavior, 54, 301-309. https://doi.org/10.1016/j.chb.2015.07.043.

Parlan, P., Ibnu, S., Rahayu, S., \& Suharti, S. (2018). Effects of metacognitive learning strategy on the quality of prospective chemistry teacher's scientific explanations. International Journal of Instruction, 11(4), 673-668. https://doi.org/10.12973/iji.2018.11442a.

Peraturan Presiden Republik Indonesia. (2017). Peraturan Pemerintah RI Nomor 19 Tahun 2017 tentang Perubahan PP Nomor 74 Tahun 2008 tentang Guru.

Pituch, K. A., \& Stevens, J. P. (2016). Applied multivariate statistics for the social sciences, analyses with SAS and IBM's SPSS, sixth edition. New York: Routledge.

Sari, D., Supahar, \& Ralmugiz, U. (2018). The influence of android-based isomorphic physics (FORFIS) application on analogical transfer and self-diagnosis skill of students. $\begin{array}{llll}\text { Jurnal Pendidikan IPA Indonesia, } & \text { 7(4), }\end{array}$ https://doi.org/10.15294/jpii.v7i2.14726.

Sawuwu, B. Y., \& Pratama, C. F. (2018). Exploring metacognitif judgement of chemistry teacher candidates on chemical reading activity. International Journal of Instruction, 11(4), 75-92. https://doi.org/10.12973/iji.2018.1146a.

Scanlon, D. (2010). Metacognitive processes. USA: American Institite for Research.

Shabrina, \& Kuswanto, H. (2018). Android-assisted mobile physics learning through Indonesia batik culture: improving student's creative thingking and problem solving. Internasational Journal of Instruction, 11(4), 287-302. https://doi.org/10.12973/iji.2018.11419a.

Scanlon, D. (2010). Metacognitive processes. USA: American Institite for Research.

Schraw, G. (1994). Assessing metacognitive awareness. Contemporary Educational Psycology.

Sumadi, C. (2015). Pengembangan media game senyawa hidrokarbon pada pembelajaran kimia di SMA Batik 1 Surakarta dan SMA Batik 2 Surakarta. Jurnal Pendidikan Kimia (JPK), 4(2), 82-88.

Sumargo, E., \& Yuanita, L. (2014). Penerapan media laboratorium virtual (phet) pada materi laju reaksi dengan model pengajaran langsung. Unesa Jornal, 3(1), 119-133.

Thiagarajan, S., Semmel, D., \& Semmel, M. (1974). Instructional development for training teachers of exception children. Indiana: Indiana University Bloomington.

Widoyoko, E. (2011). Evaluasi program pembelajaran. Yogyakarta: Pustaka Pelajar.

Yektyastuti, R., \& Ikhsan, J. (2016). Developing android-based instructional media of solubility to improve academic performance of high school students. Jurnal Inovasi Pendidikan IPA, 2(1), 88-99. https://dx.doi.org/10.21831/jipi.v2il.10289. 